\title{
Comparison of Midterm Efficiency and Complications of Tension-Free Vaginal Tape Alone and Tension-Free Vaginal Tape Performed with Vaginal Hysterectomy
}

\author{
Tek Başına Transvajinal Bant ve Transvajinal Bant ile Birlikte Yapılan Vajinal \\ Histerektominin Orta Dönem Etkinlik ve Komplikasyonlar Açısından Karşılaştırılması
}

\author{
Emre Sinan Güngör, Ağahan Han*, Hüseyin Kıyak* \\ Süleymaniye Obstetrics and Gynecology Training and Research Hospital, Clinic of Obstetrics and Gynecology, istanbul, Turkey \\ *istanbul University of Health Sciences Kanuni Sultan Süleyman Training and Research Hospital, Clinic of Obstetrics and Gynecology, Istanbul, Turkey
}

\section{Abstract}

Aim: To evaluate and compare the results and complications of tension-free vaginal tape (TVT) when performed alone or with vaginal hysterectomy $(\mathrm{VH})$ and to evaluate the mid-term success rates of TVT for both groups.

Methods: A retrospective study was performed on 179 patients who had TVT alone for stress urinary incontinance (SUI) or TVT with VH for SUI and vaginal prolapse. Demographic, outcome and complication data were obtained from medical records. The main outcome measures were postoperative SUI and voiding dysfunction.

Results: The mean age of the patients who underwent TVT and $\mathrm{TVT}+\mathrm{VH}$ were $50.2 \pm 6.8$ and $52.2 \pm 8.1$, respectively $(p>0.05)$ and the mean parity was $4 \pm 2.07$ and $4.15 \pm 2.02$, respectively $(p>0.05)$. The success rate was significantly higher in TVT alone group than in TVT+VH group ( $93.6 \%$ vs. $84.5 \%$, p<0.05). The postoperative followup period was 15.1 \pm 4.3 months for TVT group and 14.4 \pm 3.3 months for TVT+VH group ( $p>0.05)$. Overall complication rate was higher in TVT+VH group ( $4.2 \%$ vs. 9.5\%, $p<0.05$ ). Postoperative residuel urine volumes were significantly higher than preoperative residuel urine volumes in both groups $(p=0.001)$. Due to mesh rejection, second surgery was performed in one patient from both groups to reomove the mesh.

Conclusion: Midterm success rates were significantly higher in TVT group than in TVT+VH group, but success rates in TVT+VH were acceptable. Overall complication rates were higher in TVT+VH group; requirement for a second surgery was similar for both groups.

Keywords: Stress urinary incontinence, tension-free vaginal tape, pelvic surgery, prolapse repair
Öz

Amaç: Tek başına veya vajinal histerektomi (VH) ile beraber uygulandığında gerilimsiz vajinal bant (TVT) prosedürünün sonuçlarını ve komplikasyonlarını değerlendirmek ve karşılaştırmak; her iki grup için TVT'nin orta vadede sonuçlarını değerlendirmektir.

Yöntemler: Stres üriner inkontinans (SUI) nedeniyle sadece TVT uygulanan ve SUI'ya vajinal prolapsusun da eşlik ettiği durumlarda TVT ile beraber VH uygulanan 179 hasta retrospektif olarak değerlendirildi. Demografik, sonuç ve komplikasyon dataları medikal kayıtlardan elde edildi. Postoperatif SUI ve işeme disfonksiyonları ana değerlendirmelerdi.

Bulgular: Hastaların ortalama yaşları TVT ve TVT+VH için sırasıyla $50,2 \pm 6,8$ ve $52,2 \pm 8,1 \quad(p>0,05)$; pariteleri sirasiyla $4 \pm 2,07$ ve $4,15 \pm 2,02(p>0,05)$ idi. Sadece TVT uygulanan grupta başarı oranı TVT+VH uygulanan gruba göre anlamlı olarak daha yüksek idi (sırası ile $\% 93,6$ vs. \%84,5, p<0,05). Postoperatif ortalama takip süresi TVT grubu için $15,1 \pm 4,3$ ay, TVT+VH grubu için $14,4 \pm 3,3$ ay idi $(p>0,05)$. Genel komplikasyon oranı TVT+VH grubunda daha yüksekti (sırasıyla $\% 4,2$ vs. $\% 9,5, p<0,05)$. Postoperatif rezidüel idrar hacmi her iki grupta da preoperatif rezidüel hacimlere kıyasla anlamlı derecede yüksekti $(p=0,001)$. Mesh rejeksiyonu nedeni ile her iki gruptan birer hastaya mesh çıkarılması için ikincil cerrahi uygulandı.

Sonuç: Sadece TVT yapılan grupta orta dönem başarı oranı TVT+VH'den daha yüksekti ancak TVT+VH'nin de başarı oranı kabul edilebilir seviyelerde idi. Genel komplikasyon oranları TVT+VH grubunda daha yüksek; ikinci cerrahi ihtiyacı her iki grupta benzerdi.

Anahtar Sözcükler: Stres üriner inkontinans, gerilimsiz vajinal bant, pelvik cerrahi, prolapsus onarımı
Address for Correspondence/Yazışma Adresi: Emre Sinan Güngör

Süleymaniye Obstetrics and Gynecology Training and Research Hospital, Clinic of Obstetrics and Gynecology, İstanbul, Turkey

Phone: +90 5325574055 E-mail: doksinangungor@hotmail.com ORCID ID: orcid.org/0000-0002-0689-1743 Received/Geliş Tarihi: 14 July 2016 Accepted/Kabul Tarihi: 14 November 2016
${ }^{\circ}$ Copyright 2017 by The Medical Bulletin of University of Health Sciences Haseki Training and Research Hospital aseki published by Galenos Yayınevi.

Telif Hakkı 2017 Sağlık Bilimleri Üniversitesi Haseki Eğitim ve Araştırma Hastanesi Haseki Tıp Bülteni, Galenos Yayınevi tarafından basılmıștı. 


\section{Introduction}

Stress urinary incontinence (SUI) can be defined as involuntary loss of urine by physical exertion that is generally bothersome to the patient and frequently affects quality of life negatively. Approximately $15.7 \%$ of adult women are affected with this condition (1). Treatment alternatives for SUI range from conservative to surgical.

Mid-uretral slings are now the most frequently used surgical intervention for women with SUI. Tension-free vaginal tape (TVT) procedure for the treatment of female SUI was first described by UImsten et al. (2) and because of its short hospital stay, minimal injury and high cure rate, this procedure has been widely adopted. According to the latest reports, TVT is a widely used surgical technique for the treatment of SUI (3). Retropubic sling placement is considered to be a fast and effective surgery associated with an average long-term subjective cure rate of $84.3 \%$ (4).

Women undergoing surgical treatment of SUI often require concomitant pelvic organ prolapse (POP) surgery for benign uterine disorders and pelvic relaxation, such as uterine descensus, cystocele, rectocele $(5,6)$. POP (uterin descensus, cystocele, rectocele) accompanies SUI in approximetely $63 \%$ of patients (7). Therefore, for many patients with SUI, POP surgery is essential during SUI surgery. When TVT procedure is performed during POP surgery, patient is prevented from the risks of a second surgery done for SUI and it reduces the risk of anesthesia-related morbidity from a second surgery and also it reduces the costs (8). However, the efficacy of TVT performed during vaginal hysterectomy $(\mathrm{VH})$ and other pelvic floor reconstructive procedures is still controversial.

In this context, the aims of this study were; to evaluate the results and the complications of TVT procedure when performed with $\mathrm{VH}$; to compare the results in patients having TVT alone and to evaluate the mid-term success rates of TVT in both groups.

\section{Methods}

\section{Study Design}

In this retrospective study, we reviewed a cohort of 179 patients with pure stress incontinance who had undergone TVT alone or combined with pelvic floor surgery from January 2012 to July 2014. Among them, 95 women (53.1\%) underwent TVT procedure (TVT onlygroup, group 1) and 84 women (46.9\%) underwent TVT procedure after VH (TVT-hysterectomy group, group 2). The indications for $\mathrm{VH}$ were uterine prolapse, abnormal uterine bleeding or pain. Considering the whole study group, the main complaint was urinary incontinence and stress test was positive in all patients included in the study. All clinically stress-incontinent women admitted to our department for surgical correction of severe genitourinary prolapse were considered for enrollment. We included patients with a follow-up of at least 10 months in the study. Exclusion criteria were negative Q-tip test, negative stress test, intrinsic sphincter defiency (defined as a Valsalva leak point pressure of less than $60 \mathrm{~cm} \mathrm{H}_{2} \mathrm{O}$ ) and limited postoperative follow-up time (less than 10 months). None of the patients had previous incontinance surgery.

\section{Preoperative Assesment}

The urethral axis and urethrovesical junction mobility were assessed by the cotton swab test (Q-tip test). Urethral hypermobility was defined as a straining angle of more than $30^{\circ} \mathrm{C}$ (positive cotton swab test).

The degree of the prolapse was assessed in the lithotomy position while the patient performed a Valsalva maneuver. If the presenting part descends halfway to the introitus, it was defined as first-degree prolapse; if the presenting part descends to the introitus, it was defined as second-degree prolapse, and if the presenting part protrudes outside the introitus, it was defined as third-degree prolapse (9). Anterior and/or posterior colporrhaphy was planned for patients with cyctocele and/or rectocele according to pelvic examination for both groups.

Besides pelvic examination and Q-tip test; all patients underwent a full urodynamic evaluation including urethral pressure analysis, urethrocystometry, and residual urine volume measurement preoperatively. The methods, definitions, and units conformed to the standards proposed by the International Continence Society (10). A stress test was performed at a bladder volume of 350 to $450 \mathrm{~mL}$. A positive stress test was defined as the involuntary loss of urine during increased intra-abdominal pressure, without a change in the detrusor pressure. The main outcome measures were postoperative SUI, voiding dysfunction, and recurrence of prolapse.

This study was approved by Kanuni Sultan Süleyman Training and Research Hospital Ethics Committee for Clinical Investigations (approval number: 2014/5).

\section{Surgical Technique}

Two incisions, $1.5-2 \mathrm{~cm}$ length, $5 \mathrm{~cm}$ apart, were made in the skin above the superior rim of the pubic bone. The anterior vaginal wall was incised at the level of the midurethra, starting $1 \mathrm{~cm}$ from the urethral meatus, and measuring 1.5 to $2 \mathrm{~cm}$ in length. After bilateral paraurethral dissections of the vaginal wall, the bladder was pushed to the opposite side of the trocar, and tape (Betamix vaginal sling, Betatech laboratories, Turkey) was placed through 
the urogenital diaphragm into the retropubic space just behind the internal pubic bone up to the skin incision. The same procedure was performed on the other side. For patients who needed concomitant $\mathrm{VH}$ and colporrhaphy, the TVT sling was inserted afterwards the hysterectomy and colporrhaphy surgery, from a seperate incision done on the anterior vaginal wall for TVT at the level of the midurethra. The tape was then inserted as described above. All patients were operated under regional anesthesia.

\section{Postoperative Follow-up}

A Foley catheter was inserted after the TVT procedure, and was removed after 48 hours in both groups. Postvoid residual urine volumes were evaluated six hours after the removal of the catheter. In patients with intraoperative bladder injury, a Foley catheter was inserted for seven days and antibiotic was given during this period, then the postvoid residual urine was checked. The incidence of pre- and post-operative complications was recorded in all cases.

Pelvic examination and Q-tip tests were performed at every visit postoperatively. Cough stress test and multichannel urodynamic examination were performed for objective assessment at the 1 st and $12^{\text {th }}$ months postoperatively. Objective cure was defined as a negative cough stress test and no urine leakage during the multichannel urodynamic examinations. "Failure" was defined as a positive cough stress test and/or urine leakage during the urodynamic examination (11). The follow-up visits were scheduled at 1, 6, 12, and 18 months, postoperatively.

\section{Statistical Analysis}

Statistical analyses were performed using SPSS for Windows (SPSS, Chicago, USA). The data were summarized as the mean \pm standard deviation or the percentage according to the variables. Paired-samples t-test was used to compare preoperative and postoperative results. The chi-squared test was used to compare categorical variables. Student's t-test and the Mann-Whitney $U$ test were used to assess differences in group means. A p value of less than 0.05 was considered statistically significant.

\section{Results}

A total of 179 patients who underwent mid-uretral sling operations were included in the study. From these, 95 patients had TVT operation because of SUI; 84 patients had TVT+VH-colporaphy anterior-posterior (CAP) operation. All these 84 patients had symptomatic genital prolapse and SUI, which was the main indication for $\mathrm{VH}+$ CAP + TVT. The mean age and parity were not statistically different between the patients $(50.23 \pm 6.82$ vs. $52.2 \pm 8.12$ and $4 \pm 2.07$ vs. $4.53 \pm 2.01$, respectively; $p>0.05$ ). There was no statistically significant difference in body mass index, type of birth and menauposal status between the groups. The mean follow-up time was $15.18 \pm 4.3$ months for group 1 and $14.43 \pm 3.31$ months for group 2 ( $p>0.05$ ). Demographic data of the patients are shown in Table 1.

Group 1 underwent a total of 137 concomitant procedures: eight two anterior colporrhaphies, 43 posterior colporrhaphies and 12 cervical amputations. Group 2 underwent a total of 203 concomitant operations: eight four anterior colporrhaphies, 71 posterior colpoperineorrhaphies, 48 sacrospinous ligament fixation of the vaginal vault.

In group 1, one bladder perforation occured and one patient experienced mesh rejection and mesh was removed five months after the operation. Urinary retention lasting more than five days occured in two patients, urethral catheterization was performed for these patients and mesh was removed from one patient 20 days after the operation, and overall complication rate in group 1 was $4.2 \%(4 / 95)$.

In group 2, two bladder perforations occured during TVT procedure and one bladder perforation occured

\begin{tabular}{|c|c|c|c|c|c|}
\hline & \multicolumn{2}{|c|}{ TVT (n=95) } & \multicolumn{2}{|c|}{ TVT+VH $(n=84)$} & $\mathbf{p}$ \\
\hline Age & \multicolumn{2}{|c|}{$50.23 \pm 6.82$} & \multicolumn{2}{|c|}{$52.2 \pm 8.12$} & NS \\
\hline Gravida & \multicolumn{2}{|c|}{$5.03 \pm 2.18$} & \multicolumn{2}{|c|}{$4.53 \pm 2.01$} & NS \\
\hline Parity & \multicolumn{2}{|c|}{$4 \pm 2.07$} & \multicolumn{2}{|c|}{$415 \pm 2.02$} & NS \\
\hline $\mathrm{BMI}$ & \multicolumn{2}{|c|}{$28.14 \pm 3.15$} & \multicolumn{2}{|c|}{$28.71 \pm 3.15$} & NS \\
\hline Vaginal birth & 89 & $(93.6 \%)$ & 71 & $(84.5 \%)$ & NS \\
\hline Postmenapouse & 53 & $(55.8 \%)$ & 57 & $(67.8 \%)$ & NS \\
\hline Systemic disease - & 55 & $(57.8 \%)$ & 34 & $(40.4 \%)$ & \\
\hline Systemic disease + & 40 & $(42.2 \%)$ & 50 & $(59.6 \%)$ & NS \\
\hline
\end{tabular}

\begin{tabular}{|l|l|l|l|}
\hline \multicolumn{4}{|c|}{ Table 2. Perioperative and postoperative complications } \\
\hline & $\begin{array}{l}\text { TVT } \\
(\mathbf{n = 9 5 )}\end{array}$ & $\begin{array}{l}\text { TVT+VH } \\
(\mathbf{n}=\mathbf{8 4})\end{array}$ & Total \\
\hline Bladder perforation & 1 & 3 & 4 \\
\hline Mesh rejection & 1 & 1 & 2 \\
\hline Urinary retention & 2 & 4 & 6 \\
\hline Rectovaginal hematoma & 0 & 1 & 1 \\
\hline Total & $\begin{array}{l}4 / 95 \\
(4.2 \%)\end{array}$ & $\begin{array}{l}8 / 84 \\
(9.5 \%)\end{array}$ & $\begin{array}{l}12 / 179 \\
\mathrm{p}=0.001\end{array}$ \\
\hline TVT: Tension-free vaginal tape, VH: Vaginal hysterectomy \\
\hline
\end{tabular}


during VH surgery; all perforations were repaired during the operations. Urinary retention lasting more than five days occured in four patients; urethral catheterization was performed for these patients and mesh was removed from one patient 15 days after the operation. Another patient had rectovaginal hematoma, and the overall complication rate for group 2 was 9.5\% (8/84). Two patients (one from both groups) were reoperated for removal of the vaginal mesh. Complication rate was higher in group 2 (4.2\% vs. 9.5\%; $p<0.05$ ) (Table 2).

Table 3 shows the comparison of the results in both groups. Postoperative SUI was observed to be significantly lower in group 1 than in group 2 (success rate: $93.6 \%$ vs. $84.5 \%$; $p<0.05)$.

Postoperative residuel urine volumes were significantly higher than preoperative residuel urine volumes in group 1 ( $9.3 \pm 4.9$ vs. $19.8 \pm 8.6 ; p=0.0001)$. Similarly, postoperative residuel urine volumes were significantly higher than

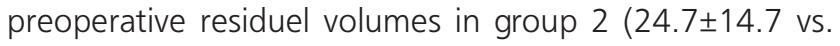
$30.5 \pm 19.4 ; p=0.0001$ ).

\section{Discussion}

SUI is frequently associated with other pelvic floor defects in women. Usually vaginal surgery is preferred because concomitant cystocele, rectocele, as well as vaginal vault suspension can be accomplished by the same approach.

There are lots of surgical techniques reported for the treatment of SUI, but midurethral sling is recognized with proven long-term success rates (80\%-85\% dry at five years in most series) and acceptable complication rates (12). Midurethral sling procedures aim to elevate and stabilize the bladder neck. As previously reported, TVT method can be considered a good alternative for the treatment of urinary incontinence $(13,14)$. The short-term results associated with this procedure are encouraging (15). Moreover, one large meta-analysis studied the surgical treatment of stress incontinence and reported that only the colposuspension and sling procedures were found

\begin{tabular}{|c|c|c|c|c|c|c|}
\hline & & TVT & up & TV & roup & $p$ \\
\hline \multirow{2}{*}{$\begin{array}{l}\text { Postop } \\
\text { SUI }\end{array}$} & Negative & 89 & $93.6 \%$ & 71 & $84.5 \%$ & \multirow[b]{2}{*}{$<0.05$} \\
\hline & Positive & 6 & $6.4 \%$ & 13 & $15.5 \%$ & \\
\hline \multirow{3}{*}{$\begin{array}{l}\text { Residual } \\
\text { volume } \\
\text { (cc) }\end{array}$} & Preop & \multicolumn{2}{|c|}{$9.3 \pm 4.9$} & \multicolumn{2}{|c|}{$24.7 \pm 14.7$} & $<0.05$ \\
\hline & Postop & \multicolumn{2}{|c|}{$19.8 \pm 8.6$} & \multicolumn{2}{|c|}{$30.5 \pm 19.4$} & $<0.05$ \\
\hline & $p$ & \multicolumn{2}{|c|}{0.0001} & \multicolumn{2}{|c|}{0.0001} & \\
\hline
\end{tabular}

to yield consistent, long-term continence rates of greater than $80 \%$ (16).

We report a cure rate of $93.6 \%$ in TVT-alone group and $84.5 \%$ in $\mathrm{TVT}+\mathrm{VH}$ group. Eventhough there was a statistically significant difference between the two groups; the success rate in group 2 patients was also high. Thubert et al. (4) reported a long-term success rate of $84.3 \%$ for retropubic sling placement. Our results are also similar with those of Darai et al. (5) and Haab et al. (15). They reported more than $90 \%$ short-term objective cure rate for the TVT-alone technique. In addition, Wei et al. (17) found that after 12 months of follow-up, $7.3 \%$ of their patients, who underwent sling surgery, required subsequent treatment for SUI.

Our urinary retention percentage was $2.1 \%$ for group 1 and $4.7 \%$ for group 2 ( $p>0.05)$. There are different reported data about postopertaive urinary retention in the literature. Partoll analyzed the outcome of TVT performed with other pelvic floor reconstructive surgeries (12) and their short-term results were good with $94 \%$ of the patients dry; urinary retention was the main postoperative complication and its frequency was $43 \%$. Different from them, in a prospective study, Gordon et al. (18) evaluated TVT performed during prolapse repair and reported that none of the patients developed postoperative SUI; postoperative de novo detrusor instability was diagnosed in four patients (13\%) and none of the patients had clinical evidence of bladder outlet obstruction. It is critical that the sling must be positioned at midurethra and not at the bladder neck, as with a traditional midurethral sling. The tape should be placed as loosely as possible to avoid urinary retention. Anterior wall procedures performed during $\mathrm{VH}$ may cause migration of the sling toward the bladder neck when the entire anterior wall is opened, thus, to avoid this problem, the tape may be placed from a different incision used from colporrhaphie anterior procedure.

Peschers et al. (19) reported that increased postoperative residual urine was far more common after combined procedures than reported after TVT alone. Similar with this study, we also found significantly higher residual urine measurement in TVT+VH group, but we also found a similar data for TVT alone group. Although residual volume increased significantly post-operatively for both groups, the increase percentage of the residual volume was significanly higher in TVT alone group when compared with TVT+VH group. These results are different from Huang et al. (20) as they found that postvoid residual volume decreased after surgery. 
The incidence of bladder perforation in both groups in our study was $1.6 \%$ which is similar with the results of Huang et al. (20) and Rafii et al. (8).

The type of anesthesia performed during surgery is also important. Huang et al. (20) reported that the efficacy and safety of the TVT procedure were irrespective of the method of anesthesia (8). We believe that the success rates of TVT surgery increases when regional anesthesia used. It protects the patient from the risks of general anesthesia and also allows cooperation with the patient during the surgery so that the patient may cough. Therefore, we performed our surgeries with reginal anesthesia.

We acknowledge the limitations of our study. A longer follow-up would make our results more powerful. The study lacked statistical power to detect small differences in rare complications.

\section{Conclusion}

As a result, TVT procedure is a safe and effective surgical technique for the treatment of SUI. Although we found a lower success rate for SUI after combined surgery, its cure rates are still high and acceptable, therefore, it seems to be logical to perform a TVT with VH to prevent the risks of second surgery. Prospective trials with larger series and longer follow-up will clarify the indeterminate points.

\section{Ethics}

Ethics Committee Approval: This study was approved by Kanuni Sultan Süleyman Training and Research Hospital Ethics Committee for Clinical Investigations (approval number: 2014/5).

Informed Consent: It was taken.

Peer-review: Externally peer-reviewed.

\section{Authorwship Contributions}

Surgical and Medical Practices: H.K., E.S.G. Concept: A.H., H.K. Design: E.S.G., A.H., H.K. Data Collection or Processing: A.H., H.K. Analysis or Interpretation: H.K., A.H. Literature Search: A.H., E.S.G. Writing: E.S.G., A.H.

Conflict of Interest: No conflict of interest was declared by the authors.

Financial Disclosure: The authors declared that this study received no financial support.

\section{References}

1. Nygaard I, Barber MD, Burgio KL, et al. Prevalence of symptomatic pelvic floor disorders in US women. JAMA 2008;300:1311-6.
2. Ulmsten $U$, Henriksson L, Johnson P, Varhos $G$. An ambulatory surgical procedure under local anesthesia for treatment of female urinary incontinence. Int Urogynecol J Pelvic Floor Dysfunct 1996;7:81-5.

3. Berger AA, Zhan T, Montella JM. The role of obesity in success and complications in patients undergoing retropubic tension-free vaginal tape surgery. Female Pel Med Recon Surg 2016;22:161-5.

4. Thubert $T$, Canel $V$, Vinchant $M$, Wigniolle I, Fernandez $H$, Deffieux X. Bladder injury and success rates following retropubic mid-urethral sling: TVT EXACT vs. TVT. Eur J Obstet Gynecol Reprod Biol 2016;198:78-83.

5. Darai E, Jeffry L, Deval B, Birsan A, Kadoch O, Soriano D. Results of tension-free vaginal tape in patients with or without vaginal hysterectomy. Eur J Obstet Gynecol Reprod Biol 2002;103:163-7.

6. Grody $\mathrm{MH}$. Urinary incontinence and concomitant prolapse. Clin Obstet Gynecol 1998;41:777-85.

7. de Tayrac R, Gervaise A, Chauveaud-Lambling A, Fernandez $H$. Combined genital prolapse repair reinforced with a polypropylene mesh and tension-free vaginal tape in women with genital prolapse and stress urinary incontinence: a retrospective case-control study with short-term follow-up. Acta Obstet Gynecol Scand 2004;83:950-4.

8. Rafii A, Paoletti X, Haab F, Levardon M, Deval B. Tension free vaginal tape and associated procedures: a case control study. Eur Urol 2004;45:356-61.

9. Beecham CT. Classification of vaginal relaxation. Am J Obstet Gynecol 1980;136:957-8.

10. Abrams PH, Blaivas JG, Stanton SL, Andersen JT. The standardization of lower urinary tract function. Neurourol Urodyn 1988;7:403-26.

11. Wang AC, Lo TS. Tension-free vaginal tape. A minimally invasive solution to stress urinary incontinence in women. J Reprod Med 1998;43:429-34.

12. Partoll LM. Efficacy of tension-free vaginal tape with other pelvic reconstructive surgery. Am J Obstet Gynecol 2002;186:1292-8.

13. Ulmsten $U$, Falconer $C$, Johnson $P$, et al. A multicenter study of tension-free vaginal tape (TVT) for surgical treatment of stress urinary incontinence. Int Urogynecol J Pelvic Floor Dysfunct 1998;9:210-3.

14. Leach GE, Dmochowski RR, Appell RA, et al. Female Stress Urinary Incontinence Clinical Guidelines Panel summary report on surgical management of female stress urinary incontinence. The American Urological Association. J Urol 1997;158:875-80.

15. Haab F, Sananes S, Amarenco G, et al. Results of the tensionfree vaginal tape procedure for the treatment of type II stress urinary incontinence at a minimum follow of 1 year. J Urol 2001;165:159-62. 
16. Jarvis GJ. Surgery for genuine stress incontinence. Br J Obstet Gynaecol 1994;101:371-4.

17. Wei JT, Nygaard I, Richter HE, et al. A Midurethral Sling to Reduce Incontinence after Vaginal Prolapse Repair. N Engl J Med 2012;366:2358-67.

18. Gordon D, Gold RS, Pauzner D, Lessing JB, Groutz A. Combined genitourinary prolapse repair and prophylactic tension-free vaginal tape in women with severe prolapse and occult stress urinary incontinence: preliminary results. Urology 2001;58:547-50.

19. Peschers UM, Tunn R, Buczkowski M, Perucchini D. Tensionfree vaginal tape for the treatment of stress urinary incontinence. Clin Obstet Gynecol 2000;43:670-5.

20. Huang KH, Kung FT, Liang HM, Huang LY, Chang SY. Concomitant surgery with tension-free vaginal tape. Acta Obstet Gynecol Scand 2003;82:948-53. 